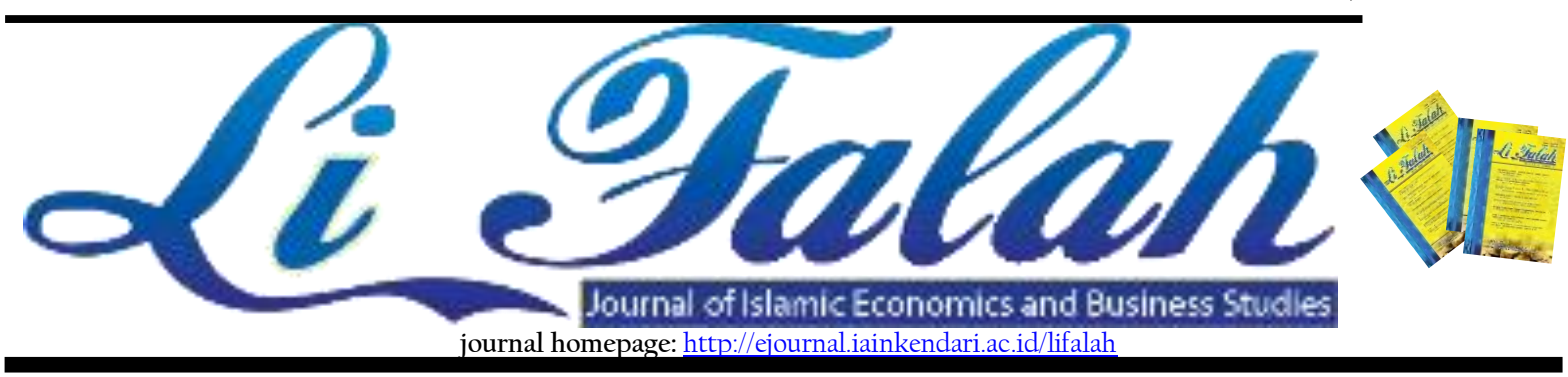

\title{
Demographics Differences in the Microfinance Clients' Perception Towards Islamic Microfinance: The Case Of Nigeria
}

\author{
Abdullateef Abdulqadir Maikabaral, Abdulmajeed M.R Aderemi², Sri Maulida ${ }^{3}$ \\ 1.IIUM Institute of Islamic Banking and Finance (IIiBF), International Islamic University Malaysia, Malaysia \\ ${ }^{2}$ Faculty of Business and Management, University Sultan Zainul Abidin, Terengganu, Malaysia \\ ${ }^{3}$ Faculty of Economics and Business, Universitas Lambung Mangkurat, Indonesia \\ e-cmail: *1 abdulqadirm2018@gmail.com, ${ }^{2}$ majeedity@gmail.com, ${ }^{3}$ srimaulida@ulm.ac.id
}

\begin{tabular}{|c|c|}
\hline ARTICLE INFO & A B S T R A C T \\
\hline $\begin{array}{l}\text { Article History: } \\
\text { Received November } 22020\end{array}$ & This paper investigates the different perceptions of \\
\hline Received in revised form 25 & Islamic microfinance. The convenience sampling \\
\hline November 2020 & technique was adopted to select the study sample to \\
\hline Available online December & collect data from the microfinance clients' beneficiaries in \\
\hline 31,2020 & $\begin{array}{l}\text { Kwara state. Four hundred data were obtained and } \\
\text { analyzed on SPSS Version } 25 \text { using descriptive analysis, }\end{array}$ \\
\hline Keywords: & independent sample $t$-test, and one-way ANOVA. The \\
\hline Demographic & findings indicate a statistically significant difference in the \\
\hline Difference, & microfinance beneficiaries' perception of their \\
\hline Perception, Islamic & demographic region, age, marital status, religion, and \\
\hline Microfinance, & education level. \\
\hline Nigeria & \\
\hline \multirow{2}{*}{\multicolumn{2}{|c|}{$\frac{\text { http://dx.doi.org/10.31332/ }}{\text { lifalah.v5i2.2260 }}$}} \\
\hline & \\
\hline (c) 2020 Li Falah. & \\
\hline
\end{tabular}

\section{Introduction}

Socio-economic development is a universal prerequisite for every nation's prospect of ensuring sustainable socio-economic wellbeing through education, employment, stable income, and better healthcare. However, over the years, this objective has not been significantly achieved by many countries despite the placement and initiation of rigorous measures by national and global bodies as the incidence of poverty seems to be an epidemic and societal disease across the world, relatively in the developed, developing and less developing countries (Maikabara A.A \& Zakariyah H., 2020) most especially in Sub Saharan Africa. Notably, according to a world bank report, in 2017, the global poverty rate amounted to 9.2 percent, which constitutes that 689 million people lived on less than $\$ 1.90$ a day, while 24.1 percent of the world lived on less than $\$ 3.20$ and relatively 43.6 percent on less than $\$ 5.50$ 
a day. Meanwhile, in 2018, four out of five people living below the global poverty line lived in rural areas as half of the poor are children, and in most regions, women were the majority. Approximately 70 percent of the poor in the world are aged between 15 and above, having primary or no education, and about 132 million poor live in flood risk areas. In Sub-Saharan Africa, half of the poor people live in Nigeria, Tanzania, Ethiopia, Madagascar, and the Democratic Republic of Congo. Even though the global plan is to tackle extreme poverty, the poverty rate is forecasted to increase. Worse after a significant decline due to the Covid-19 pandemic outbreak upon the incidence of conflicts and climate change as the negative effect of Covid-19 would pose about 88 million to 115 million people into extreme poverty, adding to the current figure account for 703 and 729 million. Tre will be 82 percent of new poor in middle-income countries like Nigeria and India (The World Bank, 2020).

In the context of Nigeria, the country has been bestowed with tremendous natural resources with a high population which more than 200 million and is one of the emerging African countries contributing to not only Africa economy but also the global economic growth as it is ranked as the $27^{\text {th }}$ largest economy in the world in term of nominal GDP (The world Bank, 2020) Despite all these, Nigeria is still considered as one of the African countries being vulnerable to poverty. According to the report of the 2019 poverty and inequality in Nigeria by the National Bureau of Statistics, 40 percent of Nigerians, which is about 83 million, live below the country's poverty line of 137,430 Naira equivalents to $\$ 381.75$ per year (The world Bank, 2020) The unemployment rate is 27.1 percent as of the second quarter of 2020 , meaning that 21.7 million Nigerians are unemployed (Nairametrics, 2020) In the financial sector, only 35 percent of the population is served by traditional commercial banks while the other $65 \%$ of the population is excluded as the poor and low-income population having no or small business and small scale farming are unprivileged to meet their basic and business financial needs (Maikabara, 2020).

The Nigerian government promoted the microfinance system to exhibit poverty eradication and financial inclusion in light of this. The microfinance system takes the responsibility of providing wide-reaching financial services, particularly in evolving markets, to the people with inadequate access to the mainstream financial market and sad to be unbankable or the people at risk of economic segregation (Aladejebi, 2019). Typically, Ledgerwood \& White (2006) describe microfinance as an effort to increase access to small credits and small savings for poor houses, which mainstream financial institutions have neglected. However, microfinance has been an essential mechanism that many developing countries have successfully used in cropping poverty and reducing unemployment among poor and underprivileged people (Rahman \& Mazlan, 2014). In 2011 the Central Bank of Nigeria 
(CBN) enacted regulatory and supervisory guidelines for Microfinance Banks in Nigeria, amended in 2012. In March 2020, this guideline was again amended and replaced by the guidelines for regulation and supervision of Microfinance Banks in Nigeria (S.P.A. Ajibade \& Co. Resources, 2020; CBN, 2020) Since 2011, many Microfinance Banks have been registered across Nigeria and provided financial services to underprivileged people in all 774 local governments of Nigeria (Okpara, 2010). As of December 2019, the CBN has licensed a total number of 913 Microfinance Banks to serve societal and economic development and financially support small and medium businesses (CBN, 2019).

Despite having many microfinance banks, the percentage of the poor people and small businesses that are financially supported is still small as many studies revealed that the microfinance banks do not significantly finance poor low-income groups and small business owners (Muhammad T \& Mamman D., 2017; Maikabara, 2020; Maikabara A.A, Aderemi A.M.R \& Maulida S., 2020) Many Nigerian Muslims cannot have access to micro-financing schemes to meet their basic and business financial needs and promote their religious faith and values. Out of the 913 microfinance banks licensed by the CBN, only a few banks are Islamic such as Albarakah Microfinance Bank, Tijarah Microfinance Bank, and some other conventional Microfinance banks offering Islamic windows (Maikabara, 2020).

In this essence, Islamic microfinance is an ethical financial institution that focuses on unprivileged or less privileged unbanked poor individuals, low-income earners, small businesses excluded by formal commercial banks microfinance banks due to their lack of creditworthiness. All the groups are financially included in the Islamic microfinance schemes and served based on their demographic characteristics ranging from gender, age, marital status, region area, religion, occupation, and monthly income. It is worth mentioning that Islamic finance, in general, accommodates all segments of society irrespective of their religious affiliation and ethnicity. Notably, many studies conducted on some geographical zones in Nigeria have shown the strong significant prospect and impact of Islamic microfinance on socio-economic development in Nigeria as it has contributed to poverty eradication and improved the household income and children education as well as it has the prospect of creating jobs (Muhammad A.D \& Muhammad A., 2013; Muhammad T \& Mamman D., 2017; Maikabara, 2020; Maikabara A.A, Aderemi A.M.R \& Maulida S., 2020).

However, despite that many rigorous studies have been conducted investigating the role of Islamic microfinance on socio-economic development, only a few studies have mainly assessed the demographic differences in the perception of microfinance beneficiaries towards Islamic microfinance, one of which is the study of Maikabara (2020) that investigated in the differences in the beneficiaries' perception towards Islamic microfinance in terms of the 
gender, occupation, and religion. This study aims to fill this research gap by examining the differences in microfinance beneficiaries' perceptions of Islamic microfinance based on their demographic characteristics. The research is organized as follows. Section 2 presents a literature review on the concept of microfinance and its historical background. Section 3 addresses the research method used in achieving the research objective as it highlights the instrument of data collection, data analysis approach, and presentation of the respondents profile. Section 4 represents the research results and analytical discussion. Lastly, section 5 concludes the research.

\section{Literature Review}

\subsection{Concept of Microfinance and its Practices}

Over the decades, the concept of microfinance has experienced an in-depth operational conceptualization due to its organic manner as a financial norm embedded with a sophisticated ecosystem having comprised of inter-dimensional financial paradigms and schemes. According to Otero (1999), Microfinance is an institution that aims at providing financial services for low-income citizens and self-employed people who have no access to financial services. Interestingly, these financial services include credit and saving, other forms of financial services, payment services, and insurance. Microfinance is a financial improvement method that encompasses offering financial services, to low-income customers, via institutions where the market fails to offer proper services (Michael, 2008). Typically, Ledgerwood \& White (2006) describe microfinance as an effort to increase access to small credits and small savings for poor houses, which mainstream financial institutions have neglected. However, microfinance has been an essential mechanism that many developing countries have successfully used in cropping poverty and reducing unemployment among poor and underprivileged people (Rahman \& Mazlan, 2014). It has also been noted that microfinance services have added to accomplishing several Millennium Development Goals' objectives (MDGs), comprising poverty mitigation via income generation (Basu, Roy, \& Karmokar, 2020). Thus, the core objective of the microfinance segment is to empower the underprivileged fellows of society financially and nurture Sustainable Development (Nor, 2019).

More comprehensively, The microfinance system takes the responsibility of providing financial services wide-reaching, particularly in evolving markets, to the people with inadequate access to the mainstream financial market and sad to be un-bankable or the people who are at risk of financial segregation (Aladejebi, 2019). The segment concentrates mostly on low-money services and products, easy access to financial mechanisms, simple primary procedures, and structured return assurances (Saeed, 2019). Underprivileged clients seek 
microfinance to solve basic needs, personal emergencies, or the expansion of a small business, among others(Kumari, Azam, Khalidah, \& Candidate, 2019). However, according to Obaidullah (2008), as cited in (Maikabara, Aderemi, \& Maulida, 2020), microfinance's major components are based on people's necessity to include micro-savings, micro-equity, microcredit, microinsurance, and micro-transfer.

Micro-savings provide microfinance that makes underprivileged people preserve money and other valuable substances and earn interest (A. A. Babajide, 2016). It allows a bunch sum to be enjoyed upcoming interchange for a sequence of savings made now (Michael Ayertey, 2008). On the other hand, microcredit provides small loans to self-employed people who are underprivileged and poor enough to qualify for mainstream financial institution loans because they cannot provide physical collateral. (Al-Shami, Majid, Mohamad, \& Rashid, 2017). Specifically, in developing countries, micro-credit allows underprivileged people to participate in self-employment ventures and businesses that make earnings, allowing them to build their level of material living and their families by themselves (Michael, 2008).

Contrarily, Islamic microfinance is an Islamic form of microfinance that provides financial services to underprivileged poor and low-income earners who are un-bankable because they are completely or fractionally excepted in the conventional microfinance system from exercising financial services due to their low economic position (Maikabara, 2020). However, there are several differences that distinguish Islamic microfinance from its conventional counterpart in both operation and scheme, such as religious elements, sources of funds, instruments, and ethical norms (Maikabara, Aderemi, \& Maulida, 2020). Islamic microfinance is a financial institution that maneuvers two missions: social and financial intermediation. Islamic microfinance is similarly a missionary organization that conveys a spiritual duty (Wediawati, Effendi, Herwany \& Masyita, 2018). Additionally, this duty is revealed in the spiritual intermediary movement to educate the people and spread the practices and ethics of Shari'ah, hence that they are expansively understood and practiced by all participants (Wulandari, Kassim, Sulung \& Putri, 2016).

\subsection{Historical Background of Microfinance in Nigeria}

Historically, the modern microfinance idea can be traced back to the 1970s when the Grameen Bank in Bangladesh, founded by the renowned pioneer Muhammad Yunus, was established (Maikabara et al. to help poor women (Michael, 2008). Remarkably, for the success of the Grameen microcredit scheme, the 1980s onwards, several governmental and non-governmental groups from corner to corner of the globe worked concerning the reproduction of the initiative because of its remarkable impact on the welfare of society (Nor, 
2019), Microfinance institution such as FINCA (Foundation for International Community Assistance) and ACCION (Americans for Community Cooperation in Other Nations) grasped to hold the market and extended through Latin America(Saeed, 2019). Subsequently, succeeding in these initial organizations' success, other microfinance institutions took off across the emerging world (Rahman \& Mazlan, 2014), including Africa (Mutalima, 2015).

Successively, in Nigeria, the practice of microfinance has been in existence for more than five decades. However, the initial years' operation was an unofficial organization (Alaro \& Alalubosa, 2019). As noted by Babajide (2011), Microfinance has been practiced in Nigeria as far as before the Central Bank of Nigeria began the announcement of microfinance banking. According to him, some organizations have been offering credit to the rural-urban poor and low-income earners, such as traditional ROSCAs (Rotating Savings and Credit Association) or formal SHGs (Self-help groups). And their other forms are referred to with different names based on various Nigerian languages; Hausa calls it Adashi while Yoruba and Igbo refer to it as Ajoor Esusu and Uto or Isuzu that respective (Maruf, 2013).

Subsequently, After some years, taking the first step into formalizing the previous informal application of microfinance services, CBS (Community Banks) was established. Still, due to numerous inadequacies and regulatory frameworks, it wasn't live long enough before it was closed down (Alaro \& Alalubosa, 2019). Instead, the first microfinance banks (MFBs) were introduced in several parts of the country to serve the poor and low-income people (Jenyo \& Adebayo, 2014). To enhance financial services to flow to MSMEs (Micro, Small, and medium enterprises) across the country in December 2005, Nigeria's Federal government laid down some regulatory framework. It established new policies for microfinance (Abiola, 2011). In 2012, the Central Bank of Nigeria also enacted regulatory and supervisory guidelines for microfinance banks in Nigeria, which has just been revised and repealed by newly drafted guidelines for the regulation and supervision of Microfinance Banks in the country implemented in April 2020 (S.P.A. Ajibade \& Co. Resources, 2020; CBN, 2020) Comparatively, apart from the regulatory guidelines covering non-interest financial services, in 2017, the CBN enacted the Guidelines for the Regulation and Supervision of Non-Interest Microfinance Banks in Nigeria (Ishaaq El-Mubarak, A.M.O., Mustapha, Z., Mohamed, A.M.T. \& Ibrahim, G., 2020) Since 2011, a total sum number of Microfinance Banks has been registered across Nigeria and providing services for underprivileged people in all 774 local governments of Nigeria (Okpara, 2010). As of December 2019, the CBN has licensed a total number of 913 Microfinance Banks to serve the societal and economic development and financially support small and medium businesses (CBN, Licensed Microfinance Banks (Mfbs) In Nigeria As At December 31, 2019 , 2019) Despite having many microfinance banks, the 
percentage of the poor people and small businesses that are financially supported is still small as many studies revealed that poor low-income groups and small business owners are not significantly financed by the microfinance banks (Muhammad T \& Mamman D., 2017; Maikabara, 2020; Maikabara A.A, Aderemi A.M.R \& Maulida S., 2020) Besides, out of the licensed Microfinance Banks, only a very few are either fully fledge Islamic Microfinance Banks or operating Islamic windows providing Islamic financial products under the conventional microfinance banks. This finding implies that even though the Muslim population is the majority in the country, there is a shortage of micro-financial institutions aiming to finance Muslims as a religious way of promoting their faith and values, which prohibited non-halal business activities and interest-bearing financing.

\section{Research Method}

This study examines the differences in the selected demographic characteristics of the study sample, the beneficiaries of the conventional microfinance banks in Kwara state. In light of this, primary and secondary data were used as the former attributes an empirical data collection from the beneficiaries. However, the latter reviewed the previous literature on the concept of microfinance and its operational background in Nigeria as research articles, books, and related materials were reviewed.

\subsection{Instrument of Data collection and procedure}

The study used a questionnaire survey as a convenience sampling technique was adopted in collecting empirical data from the beneficiaries of the conventional microfinance banks in Kwara State of Nigeria, which is statistically considered to be one of the northern-Nigerian geographical areas having more than $60 \%$ poverty rate compared to the southern part of the country. The justification for adopting convenience sampling was due to the infinity and unknown population of the beneficiaries across the state and the convenience of getting reliable and sufficient data through the sampling technique as presumed by many researchers. For this, the researchers randomly selected 400 samples. The data collected from 450 questionnaires were distributed to the state's microfinance beneficiaries. This method was used to ensure an accurate sample size of the study.

\subsection{Data Analysis}

Descriptive frequency and percentage analysis were used to report the respondents' statistical findings of the respondents' demographic characteristics. Meanwhile, the independent sample t-test and one-way ANOVA were used to inform the demographic variables' statistical differences. The data analysis was used to achieve the objective aims of the study 


\subsection{Research Hypothesis}

As this study sought to investigate the demographic differences in the perception of microfinance beneficiaries towards Islamic microfinance, the following hypotheses were predicted:

As this study sought to investigate the demographic differences in the perception of microfinance beneficiaries towards Islamic microfinance, the following hypotheses were predicted:

$\mathrm{H}_{0} \mathrm{l}$ : There is no significant difference between the gender of microfinance beneficiaries and their perception of Islamic microfinance.

$\mathrm{H}_{0}$ 2: There is no significant difference between the age of microfinance beneficiaries and their perception of Islamic microfinance.

$\mathrm{H}_{0} 3$ : There is no significant difference between the marital status of microfinance beneficiaries and their perception of Islamic microfinance.

$\mathrm{H}_{0} 4$ : There is no significant difference between the religion of microfinance beneficiaries and their perception of Islamic microfinance.

$\mathrm{H}_{0} 5$ : There is no significant difference between the region of microfinance beneficiaries and their perception of Islamic microfinance.

$\mathrm{H}_{0} 6$ : There is no significant difference between the education level of microfinance beneficiaries and their perception of Islamic microfinance.

$\mathrm{H}_{0} 7$ : There is no significant difference between the occupation of microfinance beneficiaries and their perception of Islamic microfinance.

$\mathrm{H}_{0} 8$ : There is no significant difference between the monthly household income of microfinance beneficiaries and their perception of Islamic microfinance.

3.4 Profile of the respondents

Table 1. Profile of the Respondents

\begin{tabular}{|c|c|c|c|c|}
\hline & Frequency & & Valid Percent & $\begin{array}{l}\text { Cumulative } \\
\text { Percent }\end{array}$ \\
\hline \multicolumn{5}{|c|}{ Gender } \\
\hline Male & 193 & 48.3 & 48.3 & 48.3 \\
\hline Female & 207 & 51.7 & 51.7 & 100.0 \\
\hline Total & 400 & 100.0 & 100.0 & \\
\hline \multicolumn{5}{|c|}{ Age } \\
\hline 18-30 & 176 & 44.0 & 44.0 & 44.0 \\
\hline $31-35$ & 82 & 20.5 & 20.5 & 64.5 \\
\hline $35-40$ & 91 & 22.8 & 22.8 & 87.3 \\
\hline $45-60$ & 46 & 11.5 & 11.5 & 98.8 \\
\hline 60 and above & 5 & 1.3 & 1.3 & 100.0 \\
\hline Total & 400 & 100.0 & 100.0 & \\
\hline \multicolumn{5}{|c|}{ Marital Status } \\
\hline Single & 133 & 33.3 & 33.3 & 33.3 \\
\hline Married & 260 & 65.0 & 65.0 & 98.3 \\
\hline Divorce & 6 & 1.5 & 1.5 & 99.8 \\
\hline Widow/ Widower & 1 & .3 & .3 & 100.0 \\
\hline Total & 400 & 100.0 & 100.0 & \\
\hline \multicolumn{5}{|c|}{ Religion } \\
\hline Islam & 313 & 78.3 & 78.3 & 78.3 \\
\hline Christianity & 83 & 20.8 & 20.8 & 99.0 \\
\hline Traditional & 4 & 1.0 & 1.0 & 100.0 \\
\hline Total & 400 & 100.0 & 100.0 & \\
\hline
\end{tabular}




\begin{tabular}{|c|c|c|c|c|}
\hline \multicolumn{5}{|c|}{ Region Area } \\
\hline Rural & 92 & 23.0 & 23.0 & 23.0 \\
\hline Urban & 308 & 77.0 & 77.0 & 100.0 \\
\hline Total & 400 & 100.0 & 100.0 & \\
\hline \multicolumn{5}{|c|}{ Educational Level } \\
\hline High school & 32 & 8.0 & 8.0 & 8.0 \\
\hline Diploma/ NCE & 195 & 48.8 & 48.8 & 56.8 \\
\hline Degree & 163 & 40.8 & 40.8 & 97.5 \\
\hline Master and above & 10 & 2.5 & 2.5 & 100.0 \\
\hline Total & 400 & 100.0 & 100.0 & \\
\hline \multicolumn{5}{|c|}{ Occupation } \\
\hline Civil servant & 238 & 59.5 & 59.5 & 59.5 \\
\hline Businessman/woman & 138 & 34.5 & 34.5 & 94.0 \\
\hline Both & 24 & 6.0 & 6.0 & 100.0 \\
\hline Total & 400 & 100.0 & 100.0 & \\
\hline \multicolumn{5}{|c|}{ Monthly Household Income } \\
\hline Less than $\$ 5,000$ & 37 & 9.3 & 9.3 & 9.3 \\
\hline$\$ 5,000-9,999$ & 31 & 7.8 & 7.8 & 17.0 \\
\hline$\$ 10,000-19,999$ & 66 & 16.5 & 16.5 & 33.5 \\
\hline$\$ 20,000-29,999$ & 84 & 21.0 & 21.0 & 54.5 \\
\hline$\$ 30,000$ and above & 182 & 45.5 & 45.5 & 100.0 \\
\hline Total & 400 & 100.0 & 100.0 & \\
\hline
\end{tabular}

According to the respondents' statistical data, as illustrated in Table 1, most respondents are female (207-51.7\%), which is slightly more than the male respondents (193-48.3\%). The respondents aged 18 to 30 high dominate participation in this study (176-44.0\%), whereas the least are the respondents whose ages range from 60 and above (.5-1.3\%). Interestingly, married respondents constitute a significant part of the survey (260-65.0\%), while widows or widows are the least and only amount for $(1 / .3 \%)$. However, the findings indicated positive and meaningful implications, as most respondents are Muslims (313-78.3\%). The urban respondents also dominate the survey participation (308-77.0\%), while the rural respondents are the least (92-23.0\%). Most of the respondents are Diploma or NCE holders (195-48.8\%), closely followed by degree holders, while holders of Master's or above take a tiny part of the survey (10-2.5\%). Since the respondents are stipulated to have an occupation, the primary response falls within the civil servant respondents (238-59.5\%), followed by the businessman and businesswoman respondents (138.34.5\%) as those who both civil servant and business are tiny (24/6.0\%). Lastly, most respondents have a monthly household income ranging from $\$ 30,000$ and above (182/45.5\%). In comparison, the least are respondents whose income falls relatively between $\$ 5,000-9,999$ (31/7.8\%), which is slightly different from those with less than $\$ 5,000$ as their monthly income (37/9.3\%).

\section{Result and Discussions}


The study aims to examine a statistical difference in the perception of microfinance banks beneficiaries towards Islamic microfinance and its operation to articulate and segment their financial needs and how critically and potential can be supported through Islamic microfinance schemes based on their demographic characteristics. In light of this, an independent sample $t$-test was used in analyzing the demographic differences in terms of their gender and region area where their patronized microfinance bank is situated. One-way ANOVA was also adopted to analyze the differences in terms of the beneficiaries' age, marital status, religion, education level, occupation, and monthly household income.

\begin{tabular}{llllll}
\hline \multicolumn{6}{l}{ Table 2. Gender Group Statistics } \\
\hline & Gender of the respondent & $\mathrm{N}$ & Mean & Std. Deviation & Std. Error Mean \\
\hline \multirow{2}{*}{ IMF } & Male & 193 & 43.3212 & 5.60324 & .40333 \\
\cline { 2 - 6 } & Female & 207 & 43.5604 & 5.91813 & .41134 \\
\hline
\end{tabular}

Table 3. T-test for Equality of Means (Gender)

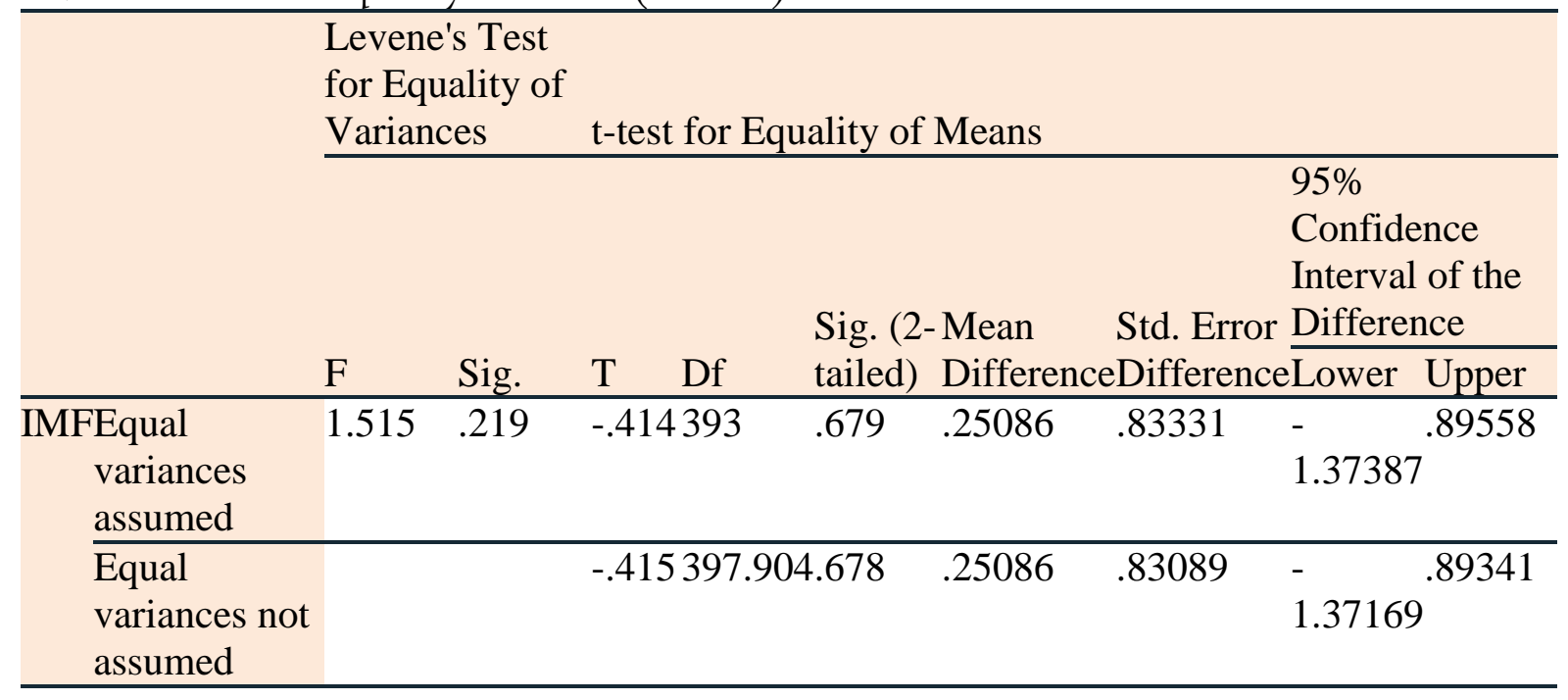

The findings of the gender group statistics of means and standard deviation, as illustrated in Table 1. indicated that the mean and standard deviation scores of male respondents seems to be in accordance as the standard deviation is closer to the mean $(m=43.3212, S D=5.60324)$ and the female scores $(m=43.5604, S D=5.91813)$ even though the female beneficiaries seems to be patronizing microfinance banks than the male. Meanwhile, Levene's test for equality of variance based on Table 3. also indicated no statistically significant difference in their perception towards Islamic microfinance with a $\mathrm{p}$-value $=.219$ which was more significant than the alpha level of 0.05 as $\mathrm{t}=(-.414) \mathrm{df}(393)=397.904, \mathrm{p}=.219$ with $95 \%$ confidence interval. The findings fail to reject the null hypothesis. The mean for males and females is not significantly different, so there is no statistically significant difference in Islamic microfinance perception. Based on the findings, it can be concluded that the female respondents, as the primary beneficiaries of the conventional microfinance banks, seem to have almost similar perceptions towards Islamic Microfinance. The findings correspond to the study of (Maikabara, 2020), 
which revealed no significant difference between male and female microfinance clients perceptions towards Islamic microfinance. This study shows the insignificance of gender inequity fallacies that behold and trigger their contribution to sustainable socio-economic development. , in light of this, Islamic microfinance, thus, has a great potential role in achieving the objectives of Sharia and the global sustainable development goals by empowering women with exclusive entrepreneurial and management skills needed for facilitating their small-medium businesses and collectively contributing to the country's socio-economic development.

\begin{tabular}{llllll}
\hline Table & 4. Regional group Statistics & & & & \\
\hline & $\begin{array}{l}\text { Region area the } \\
\text { respondent is living in }\end{array}$ & $\mathbf{N}$ & Mean & Std. Deviation & $\begin{array}{l}\text { Std. Error } \\
\text { Mean }\end{array}$ \\
\hline IMF & Rural & 92 & 43.8043 & 6.24630 & .65122 \\
\cline { 2 - 6 } & Urban & 308 & 43.3377 & 5.61608 & .32001 \\
\hline
\end{tabular}

Table 5. Test for Equality of Means (Region)

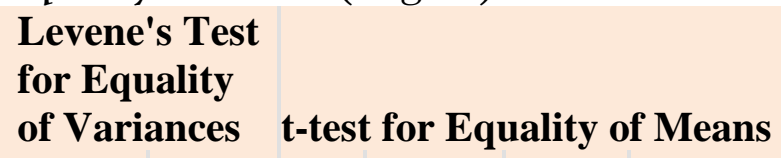

\begin{tabular}{|c|c|c|c|c|c|c|c|c|c|}
\hline & $\mathbf{F}$ & Sig. & $\mathbf{T}$ & Df & $\begin{array}{l}\text { Sig. } \\
(2- \\
\text { tailed }) \\
\end{array}$ & $\begin{array}{l}\text { Mean } \\
\text { Differenc }\end{array}$ & $\begin{array}{l}\text { Std. } \\
\text { Error } \\
\text { eDifference }\end{array}$ & $\begin{array}{l}\text { Interva } \\
\text { Differe } \\
\text { Lower } \\
\end{array}$ & $\begin{array}{l}\text { ll of the } \\
\text { nce } \\
\text { Upper }\end{array}$ \\
\hline $\begin{array}{c}\text { IMFEqual } \\
\text { variances } \\
\text { assumed }\end{array}$ & 5.553 & .019 & .681 & 398 & .496 & .46669 & .68510 & $\begin{array}{l}- \\
.88018\end{array}$ & 1.81355 \\
\hline $\begin{array}{l}\text { Equal } \\
\text { variances } \\
\text { not assumed }\end{array}$ & & & .643 & 137.8 & 0.521 & .46669 & .72560 & .96806 & 1.90143 \\
\hline
\end{tabular}

Table 4 shows that the urban region's microfinance beneficiaries have mean and standard deviation scores $(m=43.3377, S D=5.61608)$ followed by the rural beneficiaries $(m=43.8043$, $\mathrm{SD}=6.24630$ ). However, Levene's test for the equality of variance showed a statistically significant difference in their perceived value of Islamic microfinance with p-value(.019), which is higher than the alpha level of 0.05 , resulting from $\mathrm{t}=(.681)$, $\mathrm{df}(=398)=137.870, \mathrm{p}=0.00$ and a $95 \%$ confidence interval. Based on this, the null hypothesis was not rejected, so it can be concluded that there is no significant difference in the mean of the rural and urban regions, so there is no difference in the perception of microfinance beneficiaries towards Islamic microfinance. This study shows the necessity of promoting Islamic microfinance outreach in rural areas as the agrarian beneficiaries of microfinance bank services seem to have a very significant different perception of Islamic microfinance than urban segments that dominate 
formal commercial institutions and the social micro-financing institutions. This finding follows Maikabara (2020) study, which indicated a regional financial gap.

Meanwhile, there is a crucial need for financial support in the rural region where many remote villages are situated, and poverty is highly vulnerable as many poor individuals are in desperate need of basic financial amenities as well as those who are farmers with outstanding agricultural skills are hopeless due to absence or insufficient financial stand for sustaining their operation. Most of them find it difficult to financially support their children's education, which constitutes illiteracy and ignorance. The children either fall within no formal education or drop out status. In contrast, rural areas have remarkably contributed to economic development and social wellbeing through agriculture in the past decades. The policymakers are encouraged to employ collective measures in surveying the efficient operation of Islamic microfinance in the rural regions across the country, such as human capital empowerment and financial management skills to promote rural businesses and micro-agricultural financing using the Islamic microfinance instruments based on the beneficiaries' demographic, financial preference and productivity of their business projects and agricultural financial choices.

Table 6. Demographic Statistical Difference (Age)

IMF

\begin{tabular}{lllllll} 
& Sum of Squares & Df & Mean Square & F & Sig. \\
\hline Between Groups & 3334.181 & 4 & 833.545 & 13.662 & .000 \\
\hline Within Groups & 23977.279 & 393 & 61.011 & & \\
\hline Total & 27311.460 & 397 & & & \\
\hline
\end{tabular}

Above Table 5, the variance findings showed that the beneficiaries' age constitutes a significant difference in their perception of Islamic microfinance as $F(4,393)=13.662, p=.000$, which is $<0.05$. Based on this, the null hypothesis was rejected, and the alternative hypothesis was supposed. It can be concluded that there is a big significant difference in the perception of microfinance beneficiaries towards Islamic microfinance in terms of their age. It can be interpreted that many of the respondents falling under the age groups older than the young people whose ages range from 18 to 30 have zero or little knowledge about Islamic microfinance concepts and operations. This data dictates the significant difference in their perception compared to those who have proper knowledge about its operations; this might be due to their basic understanding of Islamic teachings embedded in the Islamic microfinance ecosystem. In addition, the financial privilege also constitutes the perception difference as the young people who dominated the patronage of microfinance banks have strong exposure and access to the products and operations of the banks as the promising creditworthy segment of the society with Hence, this revealed the issue of financial exclusion in microfinance system as proven in many studies. In light of this, Islamic microfinance has a financial inclusion tool 
that has a significant role to play in supporting all segments of society, be it creditworthy young group, poor or unbanked low income older people, all the age groups are financially included whereby they can be supported through the inter-dimensional instruments of Islamic microfinance ecosystem such as waqf, zakat, micro-takaful, wakalah, mudarabah and musharakah, all are structured based on their social, financial segment and ensure that they are financially independent and at the same time be productive assets to achieving sustainable socio-economic development.

Table 7. Demographic Statistical Difference (Marital status)

IMF

\begin{tabular}{lllllll} 
& Sum of Squares & Df & Mean Square & F & Sig. \\
\hline Between Groups & 996.059 & 3 & 332.020 & 10.731 & .000 \\
\hline Within Groups & 12252.731 & 396 & 30.941 & & \\
\hline Total & 13248.790 & 399 & & & \\
\hline
\end{tabular}

Table 6 presents the statistical differences in respondents' perception of Islamic microfinance in terms of marital status using one-way ANOVA. The findings revealed a significant difference in their perception towards Islamic microfinance as the statistical results are $\mathrm{F}(3,396)=10.731$, $\mathrm{p}$-value $=.000$, which is $<0.05$. The null hypothesis that there is no statistically significant difference between the beneficiaries' marital status and their perception of Islamic microfinance was rejected. Based on the findings, the beneficiaries have different perceptions due to their knowledge about Islamic microfinance operations. Some of them have the privilege to be served by microfinance banks. They have been exposed to the financial schemes compared to those who are less privileged even though they might have basic Islamic values governing the Islamic microfinance system. Meanwhile, Islamic microfinance can serve all the marital groups following their financial needs, so it is imperative to orient all the groups about the financing schemes to facilitate their financial preferences.

Table 8. Demographic Statistical Difference (Religion)

IMF

\begin{tabular}{lllllll} 
& Sum of Squares & Df & Mean Square & F & Sig. \\
\hline Between Groups & 407.445 & 2 & 203.722 & 6.298 & .002 \\
\hline Within Groups & 12841.345 & 397 & 32.346 & & \\
\hline Total & 13248.790 & 399 & & & \\
\hline
\end{tabular}

The findings indicated a significant difference between respondents' religion and their perception towards Islamic microfinance as the statistical analysis showed that $\mathrm{F}(2,397)$ $=6.298, \mathrm{p}$-value $=.002$, which is $<.005$. The null hypothesis that there is no statistically significant difference was rejected. The findings are in line with many conceptual and empirical studies which revealed the myth and misconception about the philosophy of Islamic 
finance in general, having presumed by non- Muslims as an Islamic based financial system that is mainly meant to serve Muslim financial needs, and they were so reluctant in engaging in Islamic banking and microfinance operations (Muhammad T \& Mamman D., 2017; Maikabara, 2020; Maikabara A.A, Aderemi A.M.R \& Maulida S., 2020) Also, due to a lack of expertise and knowledge in Islamic sciences, some Muslims seem to see it that way. At the same time, some of them, on the other hand, profoundly promoted it as a religious, financial system embedded with political ideologies using the name of Islam. This issue is even more powerful to trigger not only the growth of Islamic finance in the country but also the holy image of Islam as it will open a door for non-Muslims to pose a claimant of making an attempt to Islamize a multi-cultural and religious country like Nigeria and forcefully mandating Islamic ecosystem which is not contradictory to the teachings of Islam. All these issues would negatively affect the outreach and growth of Islamic finance across the country. However, it is crucial to employ training development measures at a micro level to tackle these issues by having the Islamic scholars, policymakers, finance practitioners, and journalists engage in exclusive training and seminars on Islamic science and industrial-related fields. At the macro level, the empowered bodies from the precious level will then disseminate and equip the general public with the true paradigms of every aspect of Islamic finance and affirm the philosophy of Islamic finance as a socio-economic norm and not as a religious and political domain and its great potential in serving all segment of society irrespective of their ethnic and religious affiliation.

Table 9. Demographic Statistical Difference (Education level)

IMF

\begin{tabular}{lllllll} 
& Sum of Squares & Df & Mean Square & F & Sig. \\
\hline Between Groups & 601.544 & 3 & 200.515 & 6.278 & .000 \\
\hline Within Groups & 12647.246 & 396 & 31.937 & & \\
\hline Total & 13248.790 & 399 & & & \\
\hline
\end{tabular}

According to the Table, a significant difference was found in respondents' perception towards Islamic microfinance based on their education status as F $(3,396)=6.278$, p-value $=0.00$, which is $<.005$. The null hypothesis was rejected. It can be deduced that there is a tremendous significant difference in the perception of microfinance beneficiaries towards Islamic microfinance in terms of their educational level. According to the demographic findings, most microfinance beneficiaries are diploma/NCE and degree holders. The least are holders of high school and master certificates, which implies a possible difference in perception due to educational and financial literacy. The result translates that microfinance beneficiaries' academic status influences their perception of Islamic microfinance as most of them do not know the ecosystem of Islamic microfinance. However, there is a crucial need of 
raising awareness about its products and operations as well as sensitizing and uplifting their financial literacy; this would be a great measure for Islamic microfinance to facilitate and promote education as many studies indicated that Islamic microfinance has a significant role to promote education (Rokman, 2013; Asmawat A. \& Ahmad S., 2015; ZaidMahmood H., Abbas K \& Fatima M., 2017)

Table 10. Demographic Statistical Difference (Occupation)

IMF

\begin{tabular}{lllllll} 
& Sum of Squares & Df & Mean Square & F & Sig. \\
\hline Between Groups & 61.409 & 2 & 30.704 & 924 & .398 \\
\hline Within Groups & 13187.381 & 397 & 33.218 & & \\
\hline Total & 13248.790 & 399 & & & \\
\hline
\end{tabular}

The table revealed no significant difference between the respondent's occupation and their perception towards Islamic microfinance with a statistical result of $F(2,395)=924$, pvalue $=.398$, which is $>.005$. The result failed to reject the null hypothesis. This finding affirms that the civil servants and business owners, as the majority of microfinance beneficiaries, have an excellent perception towards Islamic microfinance if widely established and operated as many Nigerians are reluctant on using the microfinance due to high interest charged and for Muslims in addition to that, the issue of non-compliance with their religious ethics but due to absence or low microfinance alternative as only a very few microfinance banks are Islamic out of a more than 900 microfinance institutions licensed by the CBN. It can also be challenging for them to quickly reach a close branch of that few Islamic microfinance institutions as they think of their trustworthiness. Islamic microfinance's significant contributions in supporting the civil servants' and businessmen's financial needs and business operations are indisputable. It caters to their financial independence and socio-economic contributions to sustainable development. The government, in collaboration with policymakers and stakeholders, should take proactive actions towards widespread of Islamic microfinance institutions across the country to serve the social needs, most especially the financial outreach of small businesses, which are considered as one of the significant segments consolidating the growth of economic development apart from business success. It can also improve their occupation opportunities and creatine for the underprivileged groups through various instruments (Muhammad T \& Mamman D., 2017; Maikabara, 2020).

Table 1l. Demographic Statistical Difference (Monthly household income)

IMF

\begin{tabular}{lllllll} 
& Sum of Squares & Df & Mean Square & F & Sig. \\
\hline Between Groups & 235.227 & 4 & 58.807 & 1.785 & .131 \\
\hline Within Groups & 13013.563 & 395 & 32.946 & & \\
\hline Total & 13248.790 & 399 & & & \\
\hline
\end{tabular}


Based on the statistical result illustrated in the table, there was no significant difference in respondents' perception towards Islamic microfinance based on their monthly household income as F (4,395) 1.785, p-value =.131, which is >.005, and the null hypothesis was not rejected. It can be concluded there was no statistically significant difference between the monthly income of microfinance beneficiaries and their perception of Islamic microfinance. This finding implies that even though the microfinance banks that are supposed to serve underprivileged small businesses and poor and low-income individuals seem to profoundly suit the financial needs of customers with credible and promising financial status as addressed in many studies, there was no difference between the perception of the beneficiaries dominating the survey and the less privileged towards Islamic microfinance. In this essence, Islamic microfinance as a tool for ensuring financial inclusion and equity has a great role in facilitating all segments of society's financial needs by developing a suitable financial scheme for each segment based on its flexibility and sophistication from not-for-profit and for-profit instruments. There might be another discussion on some practical loopholes in some Islamic microfinance institutions operating like their conventional counterparts. Hence, effective sharia governance and adequate regulatory framework is needed to enable Islamic microfinance to exhibit its mandate as proven to be viable in many studies which show its impact on improving not under asset possession and education but also improvement of income level and uplifting economic status (Rokman, 2013; Asmawat A. \& Ahmad S., 2015; ZaidMahmood H., Abbas K \& Fatima M., 2017) 


\section{Conclusion}

The study examined the significant difference between the beneficiaries of microfinance banks' demographic characteristics and their perception of Islamic microfinance. The findings revealed a statistically significant difference between the beneficiaries' perception of Islamic microfinance and their demographic age, marital status, religion, and education level. Meanwhile, no significant difference was found in their gender, region and occupation, and monthly household income. The findings revealed financial inclusion in the microfinance banks and the beneficiaries' perception of Islamic microfinance. This study constitutes a great implication on Islamic microfinance's potential role in serving the financial needs of underprivileged poor, unbanked individuals, low-income earners, and small businesses. Hence, the policymakers should employ proactive measures to raise the awareness of Islamic microfinance institutions and strengthen their wider operation. They should also ensure the implementation of proper and adequate governance for the institution to exhibit its mandate. 


\section{References}

Abiola, B. (2011). Impact Analysis of Microfinance in Nigeria. International Journal of Economics and Finance., 3(4).

Al-Shami, S. S. A., Majid, I., Mohamad, M. R., \& Rashid, N. (2017). Household welfare and women empowerment through microcredit financing: Evidence from Malaysia microcredit. Journal of Human Behavior in the Social Environment, 27(8), 894-910. https://doi.org/10.1080/10911359.2017.1345341

Aladejebi, O. (2019). The Impact of Microfinance Banks on the Growth of Small and Medium Enterprises in Lagos Metropolis. European Journal of Sustainable Development, 8(3), 261. https://doi.org/10.14207/ejsd.2019.v8n3p261

Alaro, A. A. M., \& Alalubosa, A. H. (2019). Potential of Sharīah compliant microfinance in alleviating poverty in Nigeria: A lesson from Bangladesh. International Journal of Islamic and Middle Eastern Finance and Management, 12(1), 115-129. https://doi.org/10.1108/IMEFM-012017-0021

Asmawat, A. \& Ahmad S. (2015). Impact of Islamic Microfinance on Improving the Income and Poverty Reduction of Microenterprises in Province Aceh: Case Study in Baitul Qiradh Aceh. Kontekstualita, 30(2).

Babajide, A. (2011). Impact analysis of microfinance in Nigeria. International Journal of Economics and Finance, 3(4), 217-225.

Babajide, A. A. (2016). Microsavings mobilization innovations and poverty alleviation in Nigeria. Savings and Development, 40(1), 1-28.

Basu, S., Roy, A., \& Karmokar, S. (2020). Effectiveness of Microfinance on Household Income Generation Strategy in the Southwest Region of Bangladesh. Asian Journal of Social Sciences and Legal Studies, 2(3), 56-62. https://doi.org/10.34104/ajssls.020.056062

CBN. (, 2019). Licensed Microfinance Banks (Mfbs) In Nigeria As At December 31, 2019. Retrieved October 21, 2020, from https:/www.cbn.gov.ng/Out/2020/FPRD/MFB311219.pdf

CBN. (, 2020). mfb regulation draft merged-Central Bank of Nigeria. Retrieved October 21, 2020, from The Central Bank of Nigeria: https:/www.cbn.gov.ng/out/2020/fprd/mfb\%20regulation\%20draft\%20merged.pdf

Ishaaq El-Mubarak, A.M.O., Mustapha, Z., Mohamed, A.M.T. \& Ibrahim, G. (2020). Laws of Islamic Banking in Nigeria: Critical Review and Best Practice Proposal. International Journal of Academic Research in Business and Social Sciences., 10(3), 29- 42.

Jenyo, G.K., and Adebayo, O. (2014). Performance Appraisal Of Microfinance Banks In Nigeria: A Case Study Of Selected Microfinance Banks (In Kwara State). International Journal of Small Business and Entrepreneurship Research, 2(3), 55-63.

Kumari, J. A. P., Ferdous Azam, S. M., Khalidah, S., \& Candidate, P. (2019). The effect of microfinance services on poverty reduction: analysis of empirical evidence in Sri Lankan perspectives. European Journal of Economic and Financial Research, 3, 109. https://doi.org/10.5281/zenodo.3541412

Ledgerwood, J, and White, V. (2006). Transforming Microfinance Institutions. Providing Full Financial Services to the Poor. The World Bank, Washington, D.C.

Maikabara A.A \& Zakariyah, H. (2020). Poverty Eradication in the Light of Quran and Sunnah: A Maqassid Approach. Al-Hikmah International Journal For Islamic Studies and Human Sciences, 3(3).

Maikabara, A. A. (2020). Applicability of Islamic microfinance as an alternative tool for poverty eradication in the Kwara state of Nigeria. Unpublished MSc Dissertation, International Islamic University Malaysia.

Maikabara, A. A., Aderemi, A. M. R., \& Maulida, S. (2020). Investigating the viability of the charity-based model of Islamic microfinance for eradicating the impact of covid-19 on social wellbeing in Nigeria: A descriptive analysis. Journal of Islamic Economics Perspectives, 
2(1), 114-122.

Maruf, O. (2013). Evaluation Of The Nigerian Microfinance Banks Credit Administration On Small And Medium Scale Enterprises Operations. International Review Of Management And Business Research. 2(2).

Michael Ayertey, N. (2008). Microfinance and Its Impact On Selected Districts In Eastern Region of Ghana.

Muhammad A.D \& Muhammad A. (2013). Applicability of Islamic Micro-Investment, model (IMIM) In Kano State, Nigeria: Empirical Evidence. Australian Journal of Basic and Applied Sciences, 7(4), 535-542.

Muhammad T \& Mamman D. (2017). Applicability of Islamic Microfinance Bank Solution to Poverty Reduction in the Northeast Nigeria. International Journal for Innovative Research and Development, 6(11), 25-31.

Mutalima, I. B. (2015). Responding to the voices of poor people through microfinance in Sub-Saharan Africa: an Action Research Study in Zimbabwe and Zambia. Middlesex University London.

Nairametrics. (2020). Nigeria's unemployment rate jumps to $27.1 \%$ as of 2020 Q2. Retrieved October 20, 2020, from https://nairametrics.com/2020/08/14/breaking-nigeriaunemployment-rate-jumps-to-27-1/

Nor, A. N. M. (2019). The Chronology of Microfinance Development in Malaysia: A Review. KnE Social Sciences, 2019, 1271-1284. https://doi.org/10.18502/kss.v3i22.5124

Obaidullah, M. (2008). Introduction to Islamic microfinance. India: IBF Net (P) Limited.

Okpara, G. . (2010). Microfinance Banks And Poverty Alleviation In Nigeria. Journal Of Sustainable Development In Africa. Issn, 12(6), 1520-5509.

Otero, M. (1999). Bringing development back into microfinance. Journal of Microfinance/ESR Review, 1(1), 8-19.

Rahman, M. A., \& Mazlan, A. R. (2014). Determinants of Financial Sustainability of Microfinance Institutions in Bangladesh. International Journal of Economics and Finance, 6(9), 107-116. https://doi.org/10.5539/ijef.v6n9pl07

Rokman, W. (2013). The Effect of Islamic Microfinance on Poverty Alleviation: Study in Indonesia. Journal of Economic and Business, 14(2).

Saeed, A. (2019). Microfinance as a Vehicle of Liberal Political Ideals and Pakistani State. PUTAJ - Humanities and Social Sciences, 26(1), 67-90.

S.P.A. Ajibade \& Co. Resources. (2020). Guidelines for Regulation and Supervision of Microfinance Banks in Nigeria. Retrieved October 21, 2020, from http://www.spaajibade.com/resources/guidelines-for-the-regulation-and-supervisionof-microfinance-banks-in-nigeria/

The world Bank. (2020). Nigeria Data. Retrieved October 20, 2020, from https://data.worldbank.org/country/nigeria

The world Bank. (2020). Nigeria releases a new report on poverty and inequality in the country. $\quad$ Retrieved October 20, 2020, from https://www.worldbank.org/en/programs/lsms/brief/nigeria-releases-new-report-onpoverty-and-inequality-in-country

The World Bank. (2020). Understanding Poverty. Retrieved October 20, 2020, from https://www.worldbank.org/en/topic/poverty/overview

Wediawati, B., Effendi, N., Herwany, A., \& Masyita, D. (2018). Sustainability of Islamic microfinance in Indonesia: A holistic approach. Academy of Strategic Management Journal, 17(3).

Wulandari, P., Kassim, S., Sulung, L. A. K., \& Putri, N. I. S. (2016). Unique aspects of the Islamic microfinance financing process. Humanomics.

ZaidMahmood H., Abbas K \& Fatima M. (2016). Islamic Microfinance and Household Welfare Nexus: Empirical Investigation from Pakistan. Journal of Global Entrepreneurship Research, 7(18). 